\title{
PENINGKATAN CITRA ORGANISASI MELAUI KUALITAS LAYANAN DAN EFEKTIVITAS HUMAS DI SMP SWASTA SE-KECAMATAN SUKAMAKMUR KABUPATEN BOGOR
}

\author{
Rijal Ripa'i ${ }^{a)}$, Ikhsan $^{b)}$, Dian Wulandari ${ }^{\left.b^{*}\right)}$ \\ a) Pesantren Islam Internasional Al-Andalus, Bogor, Indonesia \\ ${ }^{b)}$ Universitas Pakuan, Bogor, Indonesia \\ *)e-mail korespondensi: rijalripa31i@gmail.com
}

Riwayat artikel : diterima: 06 November 2020; direvisi: 16 November 2020; disetujui: 06 Desember 2020

\begin{abstract}
Abstrak. Perkembangan zaman telah membuat lembaga-lembaga pendidikan menjadi lembaga profit layaknya industri pada umumnya. Semakin menjamurnya lembaga-lembaga pendidikan telah menciptakan persaingan bagi para penyedia jasa pendidikan baik penyedia swasta maupun yang diselengarakan oleh pemerintah. Ungggul dari persaingan ketat menunut citra sekolah yang positif pada kalangan stakeholder. Faktanya citra sekolah, khususnya pada kalangan SMP swasta Kecamatan Sukamakmur masih belum sebagaimana diharapkan. Penelitian ini bertujuan untuk menemukan upaya meningkatkan citra organisasi suatu sekolah dengan cara menganalisis hubungannya dengan kualitas layanan dan efektivitas humas di lingkungan SMP Swasta se- Kecamatan Sukamakmur. Populasi penelitian adalah 385 peserta didik kelas 9 tahun pelajaran 2019-2020 di SMP swasta se-Kecamatan Sukamakmur Kabupaten Bogor. Sampel sebanyak 196 peserta didik diambil dengan metode proportional random sampling. Pengumpulan data untuk setiap variabel yang diteliti menggunakan angket. Teknik analisis menggunakan pendekatan korelasional menunjukkan hasil bahwa terdapat hubungan positif yang signifikan antara Kualitas Layanan dengan Citra Organisasi $\left(r_{\mathrm{y} 1}=0,785\right)$, terdapat hubungan positif yang signifikan antara Efektivitas Humas dengan Citra Organisasi $\left(\mathrm{r}_{\mathrm{y} 2}=0,401\right)$, dan terdapat hubungan positif antara Kualitas Layanan dan Efektivitas Humas secara bersamasama terhadap Citra Organisasi $\left(\mathrm{r}_{\mathrm{y} 12}=0,794\right)$. Dapat disimpulkan bahwa Citra organisasi dapat ditingkatkan melalui penguatan Kualitas Layanan dan Efektivitas Humas secara parsial maupun bersama-sama.
\end{abstract}

Kata Kunci: citra organisasi; kualitas layanan; efektivitas humas

\section{IMPROVING THE ORGANIZATION IMAGE THROUGH THE SERVICE QUALITY AND COMMUNITY RELATIONSHIP EFFECTIVENESS ON PRIVATE JUNIOR HIGH SCHOOLS AT SUKAMAKMUR, KABUPATEN BOGOR}

\begin{abstract}
The educational institution has changed into profit industrial institutions as the impact of era change. The proliferation of educational institutions has created competition for education service providers, both private and public schools. This competition is absolute and is getting tighter, especially for private educational institutions. To win the competition, school should build a positive image on all stakeholders. On the contrary, at Sukamakmur District, it is found that the school image is still relatively low. This research aimed to improve school organizational image by analyzing its relationship between service quality and public relations effectiveness. The research was taken in private junior high schools in Sukamakmur District Bogor Regency. The study population was 385 students of grade 9 of 2019-2020 Academic Year. The sample taken was 196 students by using proportional random sampling. The data was collected by using a questionnaire with a scale (Rating Scale). The analysis technique used a survey method and a correlational approach. The results showed that there was a relationship between service quality and organizational image (ryl = 0.785). There was a relationship between public relations effectiveness and organizational image $($ ry $2=0.401)$, There was a relationship between service quality and public relations effectiveness on organizational image (ry12=0.794). It can be concluded that the organization image could be improved by service quality and public relations effectiveness partially or collectively.
\end{abstract}

Keywords: organizational image; service quality; public relations effectiveness

\section{PENDAHULUAN}

Pada era global saat ini, dimana dunia pendidikan bukan lagi hanya bertujuan mencerdaskan kehidupan bangsa. Lebih dari itu telah terjadi perkembangan orientasi lembaga-lembaga pendidikan, khususnya lembaga pendidikan yang diselengarakan oleh swasta. Tidak dapat dipungkiri saat ini lembaga-lembaga pendidikan yang ada telah berorientasi menjadi lembaga profit layaknya dunia industri pada umumnya. Berkembangnya penyedia jasa pendidikan menjadi industri pendidikan dipicu oleh perkembangan wawasan masyarakat terhadap globalisasi dan perkembangan teknologi, tumbuhnya waralaba pendidikan asing dan berbagai sekolah yang mengidentitaskan sebagai unggulan, kerjasama pendidikan asing dengan pendidikan dalam negeri, bermunculannya berbagai kursus dan program luar sekolah, serta beroperasinya penyedia jasa pendaftaran pendidikan ke luar negeri. Berdasarkan data referensi Kementrian Pendidikan dan Kebudayaan pada tahun 2017 di Propinsi Jawa Barat terdapat 2.154 sekolah negeri dan 5.917 SMP swasta, 
(http://referensi.data.kemdikbud.go.id : 2017). Berkembangnya penyedia jasa pendidikan menjadi industri pendidikan, sedikit banyak berdampak pada pergeseran tujuan pendidikan, dari mencerdaskan kehidupan bangsa menjadi mulai berfokus pada mencermati pangsa pasar yang terus berubah. Dampaknya, prinsip pengelolaan lebih menyerupai pengelolaan perusahaan-perusahaan industri lainnya.

Citra sebuah lembaga merupakan salah satu harta yang bernilai tinggi bagi suatu lembaga manapun karena baik buruknya lembaga ditentukan oleh citranya dimata para pemangku kepentingan. Citra organisasi adalah cara pandang atau persepsi masyarakat terhadap lembaga tersebut. Citra yang baik harus dibangun, dan dikelola sehingga mampu memberikan keuntungan atau manfaat bagi lembaga bersangkutan. Citra organis asi yang baik merupakan salah satu kunci menang dalma persaingan. Sekolah swasta khususnya perlu mengelola citra secara sungguh-sungguh, karena jika citra sekolah positif akan mendorong masyarakat untuk mengunakan layanan pendidikan sehingga sekolah dapat terus beroperasi. Sebaliknya citra sekolah yang negatif membuat masyarakat enggan mempercayakan pendidikan pada lembaga tersebut. Jika hal ini tidak dikelola maka sekolah dapat kehilangan peminat yang berujung pada penurunan jumlah peserta didik bahkan sampai mengalamu kebangkrutan. Citra sekolah yang baik akan membuat orang percaya pada kualitas layanan pendidikan di sekolah, membuat orangtua peserta didik berbondong-bondong mendaftarkan putra-putrinya ke sekolah tersebut sehingga kapasitas sekolah dapat terisi optimal. Kondisi ini tentu membuat sekolah memiliki sumberdaya finansial yang cukup untuk memfasilitasi berbagai kegiatan pembelajaran dan penunjang, baik bersifat akademis maupun non-akademis, sekolah mampu menyediakan sarana prasarana sekolah yang berdampak pada pengembangan sekolah sehingga tujuan sekolah dapat dicapai maksimal. Namun pada kenyataannya, belum seluruh sekolah memberikan perhatian khusus pada pengelolaan citra sekolah.

\section{Citra Organisasi}

Oliver (2007:50) mengatakan citra adalah suatu gambaran tentang mental, ide yang dihasilkan oleh imaginasi atau efektivitas humas yang ditunjukan kepada publik oleh seseorang, organisasi dan sebagainnya. Menurut Nguyen \& Leblanc (dalam Matei \& Dinu 2010:165) Citra perusahaan merupakan keseluruuhan kesan yang terbentuk dibenak masyarakat tentang perusahaan. Elliot (2007:209) menyatakan bahwa citra perusahaan adalah seperangkat persepsi tentang perusahaan yang dimiliki oleh berbagai pemangku kepentingan termasuk pelaggan, karyawan, pemegang saham dan media. Dari paparan teoriteori mengenai citra organisasi, dapat disintesiskan bahwa citra organisasi/perusahaan (corporate image) adalah keseluruhan kesan, persepsi, informasi, dan respon yang terbentuk pada benak seluruh pemangku kepentingan termasuk pelanggan, karyawan, pemegang saham, dan media terhadap suatu organisasi dikaitkan dengan realitas yang muncul berkenaan dengan aktivitas organisasi dari waktu ke waktu. Setiap organisasi tentu melaksanakan program yang dimulai dari tahap perencanaan sampai pada evaluasi (Karmila \& Suchyadi, 2020). Adapun indikator citra organisasi adalah: (1) Reputation; (2) Corporate Identity; (3) Corporate Capability; (4) Sosial Responsibility.

\section{Kualitas Layanan}

Kualitas layanan sangat penting untuk mempertahankan konsumen (Patras, 2020). Berkaitan dengan pengertian mengenau kualitas layanan, Baines et al. (2011:504) menyatakan bahwa service quality adalah persepsi pelanggan terhadap perbedaan antara layanan yang diterima dibandingkan dengan layanan yang diharapkan. Sejalan dengan hal tersebut, Rangkuti (2008:17) menyatakan bahwa kualitas pelayanan merupakan suatu bentuk penilaian konsumen terhadap pelayanan yang diterima (perceived service) dengan tingkat layanan yang diharapkan (expected service). Gronroos (dalam Tangkilisan, 2007:218) menyatakan kualitas layanan adalah suatau perbandingan antara apa yang dirasa para konsumen harus ditawarkan oleh perusahaan yang memberikan jasa atau pelayanan. Berdasarkan teori-teori mengenai kualitas layanan di atas maka dapat disintesiskan bahwa kualitas layanan adalah suatu bentuk penilaian dan persepsi konsumen secara menyeluruh terhadap ukuran dan tingkat keunggulan pelayanan yang diterima (perceived service) dengan ukuran dan tingkat layanan yang diharapkan (expected service) dalam rangka memberikan kepuasan kepada pelanggan. Indikator untuk mengukur kualitas layanan yaitu: (1) Reliability (kehandalan), (2) Responsiveness ( Ketanggapan), (3) Assurance (Jaminan), (4) Empathy (Empati), (5) Tangibles (Benda berwujud).

\section{Efektivitas Humas}

Salah satu faktor yang berhubungan dengan citra organisasi adalah efektivitas humas. Mulyasa (2012:23) menyatakan bahwa efektivitas menunjukan adanya kesesuaian antara orang yang menjalankan tugas dengan sasaran yang dituju, serta menunjukan bagaimana suatu organisasi berhasil mendapatkan dan memanfaatkan sumber daya dalam usaha mewujudkan tujuan operasional. Efektivitas adalah keterkaitan antara tujuan dan hasil yang didapatkan, dan menunjukkan kesesuaian antara tujuan yang ditetapkan dengan hasil yang dicapai. Penelitian yang dilakukan Menix (2007:204) menyimpulkan bahwa effectiveness is having the intended results and outcomes occur. Both internal and external influences can affect program and organizational abilities to achieve effectiveness. Berkaitan dengan pemahaman mengenai hubungan masyarakat, Kotler dan Armstrong (2008:117) menyatakan bahwa hubungan masyarakat (Public Relation) adalah aktivitas membangun hubungan baik dengan berbagai kalangan untuk mendapatkan publisitas yang diinginkan. Menurut Jekfinis (dalam Puspokusumo, 2011:205) public relation adalah suatu rangkaian kegiatan yang dilakukan secara terpadu yang dilakukan secara berkesinambungan serta teratur untuk mencapai tujuan-tujuan yang telah 
ditetapkan oleh organisasi. Berdasarkan teori-teori mengenai efektivitas dan hubungan masyarakat tersebut, maka dapat disintesiskan bahwa efektivitas humas (public relation) adalah kesesuaian antara tujuan dan pelaksana segala bentuk aktivitas kontak atau hubungan yang dilakukan dengan sengaja suatu organisasi untuk mempengaruhi persepsi, opini, keyakinan, dan sikap publik; baik publik internal maupun eksternal dengan ketercapaian tujuan atau hasil yang diharapkan oleh organisasi tersebut. Indikator untuk mengukur efektivitas hubungan masyarakat (public relation) terdiri dari: (1) Kemudahan berkomunikasi (2) Kecakapan meredam isu negatif (3) Kemampuan menyelesaian konflik (4)Penyampaian berita

\section{METODE PENELITIAN}

Penelitian ini menggunakan pendekatan kuantitatif dengan metode survei korelasional. Variabel bebas dalam penelitian ini adalah Kualitas Layanan $\left(\mathrm{X}_{1}\right)$ dan Efektivitas Humas $\left(\mathrm{X}_{2}\right)$, sedangkan variabel terikat $(\mathrm{Y})$ adalah Citra Organisasi. Populasi dalam penelitian ini yaitu SMP Swasta se-Kecamatan Sukamakmur Kabupaten Bogor dengan responden peserta didik kelas 9 tahun pelajaran 2019-2020 sebanyak 385 orang dengan sampel sebanyak 196 orang yang ditentukan berdasarkan rumus Taro Yamane. Pengambilan sampel pada masing-masing Pesantren dilaksanakan dengan teknik propotional random sampling. Analisis data diawali dengan analisis persyaratan analisis, yaitu: uji normalitas galat baku taksiran dan uji homogenitas varian.

\section{HASIL DAN PEMBAHASAN}

\section{Pengujian persyaratan analisis Uji Normalitas}

Uji Normalitas Galat Baku yang digunakan adalah Uji Liliefors dengan taraf signifikansi 0,05. Hasil perhitungan normalitas galat baku taksiran $\left(\mathrm{Y}-\mathrm{X}_{1}\right)$ variabel Citra Organisasi $(\mathrm{Y})$ atas varibel Kualitas Layanan $\left(\mathrm{X}_{1}\right)$ diperoleh skor $\mathrm{L}_{\mathrm{hitung}}$ maksimum sebesar 0,057717 dengan $\mathrm{L}_{\text {tabel }}$ sebesar 0,0637 pada taraf signifikan 0,05, dengan demikian galat baku taksiran $\left(\mathrm{Y}-\mathrm{X}_{1}\right)$ berdistribusi normal. Sementara data yang dihasilkan pada perhitungan normalitas galat baku taksiran $\left(\mathrm{Y}-\mathrm{X}_{2}\right)$ variabel Citra Organisasi (Y) atas variabel Efektivitas Humas $\left(\mathrm{X}_{2}\right)$ adalah skor $\mathrm{L}_{\text {hitung }}$ sebesar 0,046541 dengan $\mathrm{L}_{\text {tabel }}$ sebesar 0,0637 pada taraf signifikan 0,05. Dengan demikian, data juga disimpulkan berasal dari populasi yang berdistribusi normal.

\section{Uji Homogenitas}

Uji ini dimaksudkan untuk menguji kesamaan varians populasi yang berdistribusi normal. Uji homogenitas yang digunakan adalah Uji Barlett, diuji dengan taraf signifikansi 0,05. Uji homogenitas varians kelompok data Citra Organisasi (Y) dengan variabel Kualitas Layanan $\left(\mathrm{X}_{1}\right)$ didapatkan skor $\chi_{\text {hitung }}^{2}$ sebesar 53,883 sedangkan $\chi_{\text {tabel }}^{2}(0,05)$ sebesar 62,829 . Dapat disimpulkan bahwa varians skor data variabel Citra Organisasi ( $Y$ ) dengan Kualitas Layanan $\left(\mathrm{X}_{1}\right)$ berasal dari populasi homogen. Hasil perhitungan uji homogenitas varians kelompok data Citra Organisasi (Y) dengan variabel Efektivitas Humas $\left(\mathrm{X}_{2}\right)$, didapatkan skor $\chi^{2}{ }_{\text {hitung }}$ sebesar 45,251 sedangkan $\chi_{\text {tabel }}^{2}(0,05)$ sebesar 48,602. Sehingga dapat disimpulkan bahwa varians skor data variabel Citra Organisasi $(\mathrm{Y})$ dengan Efektivitas Humas $\left(\mathrm{X}_{2}\right)$ berasal dari populasi homogen.

\section{Pengujian Hipotesis}

\section{Hubungan antara Kualitas Layanan dengan Citra Organisasi}

Hasil pengolahan data menunjukkan analisis regresi linier sederhana antara Kualitas Layanan $\left(\mathrm{X}_{1}\right)$ dengan Citra Organisasi (Y) nilai konstanta regresi sebesar 22,673 dan koefisien regresi sebesar 0,884, sehingga dapat dibuat persamaan regresinya adalah $\hat{\mathrm{Y}}=0,969+0,946 \mathrm{X}_{1}$. Persamaan ini signifikan pada $\alpha(0,05)$. Kenaikan skor pada variabel Kualitas Layanan $\left(\mathrm{X}_{1}\right)$ akan menyebabkan kenaikan skor pada variabel Citra Organisasi (Y). Persamaan regresi tersebut juga memiliki arti bahwa tanpa kehadiran variabel Kualitas Layanan $\left(\mathrm{X}_{1}\right)$, citra organisasi SMP Swasta se-Kecamatan Sukamakmur Kabupaten Bogor (Y) dengan skor 0,969. Analisis korelasi sederhana diperoleh nilai $r=0,785$, maka dapat disimpulkan bahwa hubungan antara variabel Kualitas Layanan $\left(\mathrm{X}_{1}\right)$ dengan Citra Organisasi $(\mathrm{Y})$ mempunyai hubungan yang sangat kuat dan dengan melihat hasil sig. (2-tailed) sebesar 0,000 ini menunjukkan bahwa kedua variabel memiliki hubungan yang sangat kuat dan signifikan. Maka tolak $\mathrm{H}_{0}$ dan terima $\mathrm{H}_{\mathrm{a}}$, artinya terdapat hubungan positif antara Kualitas Layanan dengan Citra Organisasi. Kontribusi Kualitas Layanan $\left(\mathrm{X}_{1}\right)$ yang secara langsung berkontribusi terhadap variasi pada variabel Citra Organisasi $(Y)=0,785^{2}=0,6164=61,64 \%$.

\section{Hubungan antara Efektivitas Humas dengan Citra Organisasi}

Hasil analisis regresi linier sederhana antara Efektivitas Humas $\left(\mathrm{X}_{2}\right)$ dengan Citra Organisasi (Y) nilai konstanta regresi sebesar 58,603 dan koefisien regresi sebesar 0,503, sehingga dapat dibuat persamaan regresinya adalah $\hat{Y}=27,662+$ $0,764 \mathrm{X}_{2}$, ini menunjukkan bahwa hubungan fungsional antara Efektivitas Humas $\left(\mathrm{X}_{2}\right)$ dengan Citra Organisasi (Y) mempunyai hubungan positif dan signifika pada $\alpha(0,05)$. Kenaikan skor pada variabel Efektivitas Humas $\left(\mathrm{X}_{2}\right)$ akan menyebabkan kenaikan skor pada variabel Citra Organisasi (Y). Persamaan regresi tersebut juga memiliki arti bahwa tanpa 
kehadiran variabel Efektivitas Humas $\left(\mathrm{X}_{2}\right)$, citra organisasi SMP Swasta se-Kecamatan Sukamakmur Kabupaten Bogor (Y) dengan skor 27,662. Analisis korelasi sederhana diperoleh nilai $\mathrm{r}=0,401$, maka dapat disimpulkan bahwa hubungan antara variabel Efektivitas Humas $\left(\mathrm{X}_{2}\right)$ dengan Citra Organisasi $(\mathrm{Y})$ mempunyai hubungan yang sangat kuat dan dengan melihat hasil sig. (2-tailed) sebesar 0,000 ini menunjukkan bahwa kedua variabel memiliki hubungan yang sangat kuat dan signifikan. Maka tolak $\mathrm{H}_{0}$ dan terima $\mathrm{H}_{\mathrm{a}}$, artinya terdapat hubungan positif antara Kualitas Layanan dengan Citra Organisasi. Kontribusi Efektivitas Humas $\left(\mathrm{X}_{2}\right)$ yang secara berkontribusi terhadap variasi Citra Organisasi $(\mathrm{Y})=0,401^{2}=0,1607=$ $16,07 \%$.

\section{Hubungan antara Kualitas Layanan dan Efektivitas Humas secara bersama-sama dengan Citra Organisasi.}

Analisis regresi linier sederhana antara Kualitas Layanan $\left(\mathrm{X}_{1}\right)$ dan Efektivitas Humas $\left(\mathrm{X}_{2}\right)$ dengan Citra Organisasi (Y) konstanta regresi sebesar -24,205 dan koefisien regresi $b_{1}$ sebesar 0,890, dan koefisien regresi $b_{2}$ adalah 0,236 sehingga dapat dibuat persamaan regresinya adalah $\hat{\mathrm{Y}}=-24,205+0,890 \mathrm{X}_{1}+0,236 \mathrm{X}_{2}$. Nilai $\mathrm{F}_{\text {hitung }}=164,069$ atau dengan melihat nilai Sig. $0.000_{\mathrm{b}}$ menunjukkan bahwa $\mathrm{H}_{0}$ ditolak dan Ha diterima, artinya bahwa Kualitas Layanan $\left(\mathrm{X}_{1}\right)$ dan Efektivitas Humas $\left(\mathrm{X}_{2}\right)$ secara bersama-sama berpengaruh secara signifikan dan simultan terhadap Citra Organisasi (Y). Nilai koefisien korelasi $\left(\mathrm{r}_{\mathrm{y} 1.2}\right)$ sebesar 0,794 serta koefisien determinasi $\left(\mathrm{R}_{\mathrm{y} 1.2^{2}}\right)$ sebesar 0,630. Kontribusi Kualitas Layanan $\left(\mathrm{X}_{1}\right)$ dan Efektivitas Humas $\left(\mathrm{X}_{2}\right)$ secara bersama-sama yang secara langsung berkontribusi terhadap variasi Citra Organisasi $(\mathrm{Y})=$ $0,630=63 \%$

\section{Korelasi parsial}

Hasil Output SPSS antara Kualitas Layanan $\left(\mathrm{X}_{1}\right)$ dengan Citra Organisasi (Y) dengan kontrol Efektivitas Humas $\left(\mathrm{X}_{2}\right)$ didapati nilai signifikansi sebesar 0,000 yang berarti kurang dari $\alpha(0,05)$, dengan demikian koefisien korelasi antara $\mathrm{X}_{1}$ dan $\mathrm{Y}$ dengan kontrol $\mathrm{X}_{2}$ sebesar 0,747 lebih dari 0 dinyatakan memiliki hubungan positif dan sangat signifikan. Hasil Output SPSS antara Efektivitas Humas $\left(\mathrm{X}_{2}\right)$ dengan Citra Organisasi $(\mathrm{Y})$ dengan kontrol Kualitas Layanan $\left(\mathrm{X}_{1}\right)$ menghasilkan nilai signifikansi sebesar 0,009 yang berarti kurang dari $\alpha(0,05)$, dengan demikian koefisien korelasi antara $\mathrm{X}_{2}$ dan $\mathrm{Y}$ dengan kontrol $\mathrm{X}_{1}$ sebesar 0,186 lebih dari 0 dinyatakan memiliki hubungan positif dan sangat signifikan.

\section{Pembahasan}

Berdasarkan perhitungan uji regresi linier sederhana dan uji korelasi sederhana, didapati bahwa terdapat hubungan positif antara Kualitas Layanan dengan Citra Organisasi. Analisis korelasi sederhana kedua variabel menghasilkan koefisien korelasi $\left(\mathrm{r}_{\mathrm{y} 1}\right)$ sebesar 0,785 , sehingga didapatkan nilai koefisien dereminasinya $\left(\mathrm{r}_{\mathrm{y} 1}{ }^{2}\right)$ adalah 0,6164 menunjukkan variabel Kualitas Layanan memberikan kontribusi sebesar 61,64\% terhadap kenaikan Citra Organisasi. Hasil penelitian ini juga sejalan dengan hasil penelitian Eman Mohamed Abd-El-Salam, Ayman Yehia Shawky dan Tawfik El-Nahas, tahun 2013 melalui artikel berjudul "The impact of corporate image and reputation on service quality, customer satisfaction and customer loyalty: testing the mediating role. Case analysis in an international service company", menyatakan terdapat hubungan positif yang signifikan antara kualitas layanan terhadap citra organisasi. Yang dibuktikan dengan nilai $r=0,210$ $(\rho<0,01)$. Hasil penelitian ini juga menyimpulkan adanya hubungan positif antara Efektivitas Humas $\left(\mathrm{X}_{2}\right)$ dengan Citra Organisasi (Y). Analisis korelasi sederhana kedua variabel menghasilkan koefisien korelasi ( $\mathrm{r}_{\mathrm{y} 2}$ ) sebesar 0,401 , sehingga didapatkan nilai koefisien dereminasinya $\left(\mathrm{r}_{\mathrm{y} 2}{ }^{2}\right)$ adalah 0,1607 menunjukkan variabel Efektivitas Humas memberikan kontribusi sebesar 16,07\% terhadap kenaikan Citra Organisasi.

Hasil penelitian ini didukung pula oleh hasil penelitian Fatimah Abdillah (2017) dengan judul "Efektivitas Marketing Public Relation dalam Membangun Citra Merek Perusahaan Jasa Telekomunikasi”, menyatakan angka koefisien korelasi rank spearman 0,692 membuktikan bahwa marketing public relations (MPR) memiliki peranan yang cukup kuat terhadap citra merek Smartfren; Hasil Peneliitian Fony Pangandaheng (2015) dengan judul "Pengaruh Kualitas Layanan dan kepuasan pelanggan terhadap Citra Perusahaan dan Dampaknya Terhadap Loyalitas Pelanggan pada PT. Hadji Kalla Palu", menunjukan adanya pengaruh signifikan kualitas layanan yang terdiri dari bukti fisik, kehandalan, daya tanggap, jaminan dan empati terhadap kepuasan pelanggan terhadap citra perusahaan. Kesimpulan ini berdasarkan nilai CR yang dicapai lebih besar dari CR minimal yang disyaratkan sebesar 2,00 pada probability ( $\rho$ ) sebesar 0,000 lebih kecil dari 0,05 yang menandakan bahwa kedua variabel memiliki pengaruh yang signifikan. Hasil uji signifikansi korelasi ganda diperoleh $\mathrm{F}_{\text {hitung }}=76,667$ dengan sig 0,000, maka hipotesis yang diterima adalah $\mathrm{H}_{1}$. Dapat ditarik kesimpulan terdapat hubungan positif yang sangat signifikan antara Kualitas Layanan $\left(\mathrm{X}_{1}\right)$ dan Efektivitas Humas $\left(\mathrm{X}_{2}\right)$ secara bersama-sama dengan Citra Organisasi (Y). Beradasarkan skor koefisien korelasi $r_{\mathrm{y} 12}=0,794$ serta koefisien determinasi $\left(\mathrm{R}_{\left.\mathrm{y} 1.2^{2}\right)}\right.$ sebesar 0,630 atau 63 $\%$. Dengan demikian, antara Kualitas Layanan $\left(\mathrm{X}_{1}\right)$ dan Efektivitas Humas $\left(\mathrm{X}_{2}\right)$ secara bersama-sama dengan Citra Organisasi (Y) adalah sebesar 63\% sedangkan sisanya sebesar 37\% adalah kontribusi dari variabel lain yang tidak diteliti. Dari uraian diatas, berdasarkan data dan fakta penelitian, bahwa upaya peningkatan Citra Organisasi dapat dilakukan dengan penguatan Kualitas Layanan dan Efektivitas Humas. Adapun cara dan strategi agar terjadi peningkatan Citra Organisasi adalah dengan memperhatikan indikator-indikator pada variabel. Implikasi dari penelitian ini adalah jika Lembaga Pendidikan, khususnya SMP swasta ingin meningkatkan citra organisasi sekolahnya, dapat dilakukan melalui penguatan efektivitas humas berupa kegiatan CSR (corporate social responsibility) kepada masyarakat sekitar yang diharapkan membawa citra positif bagi sekolah. Hal lain, sekolah terus mengupayakan penguatan reputasi melalui perolehan capaian 
prestasi warga sekolah baik peserta didik, maupun gurunya. Upaya peningkatan citra positif sekolah dapat pula dilakukan melalui peningkatan kualitas layanan, misalnya dengan memperbaiki sarana fisik sehingga tercitrakan sebagai sekolah yang memiliki fasilitas pendidikan yang lengkap. Upaya lain dapat ditunjukkan melalui ketanggapan tinggi dari seluruh pendidik, tenaga Pendidikan dan kepala sekolah dalam mengatasi masalah di sekolah, atau dalam beradaptasi dalam perubahan situasi lingkungan. Peningkatan citra sekolah melalui kualitas layanan dapat diusahakan dengan cara menunjukkan layanan yang ajeg kepada siapapun dan dalam berbagai kondisi.

\section{SIMPULAN}

Penelitian ini menyimpulkan: 1) terdapat hubungan positif dan signifikan antara Kualitas Layanan dengan Citra Organisasi, 2) terdapat hubungan positif dan signifikan antara Efektivitas Humas dengan Citra Organisasi, 3) terdapat hubungan positif dan signifikan antara Kualitas Layanan dan Efektivitas Humas secara bersama-sama dengan Citra Organisasi, 4) Citra Organisasi dapat ditingkatkan melalui penguatan Kualitas Layanan dan Efektivitas Humas dengan cara dan strategi mempertahakan dan memperbaiki indikator-indikator pada variabel. Penelitian lanjutan mengenai citra organisasi, khususnya citra organisasi sekolah dapat dilakukan dengan mengkaji hubungannya dengan variabel lain, misalnya literasi IT para tenaga pendidik, mengingat saat ini layanan sekolah membutuhkan literasi IT tinggi. Metode penelitian mengenai citra organisasi dapat dikembangkan dengan menggali lebih teliti mengenai kontribusi indikator-indikator variabel penelitian dengan teknik analisis jalur aatu SEM (structural equation method)

\section{REFERENSI}

Baines, Paul, et.al. (2011). Marketing. Oxford University Press. New York

Cornelissen, Joep. P, (N.d) Corporate Communication : A Guide to Theory and Practice, Second Edition, Wiltsire, The Cromwell Press.

Deitiana, Tita. (2011). Manajemen Humas di lembaga Pendidikan. Media Bisnis STIE Trisakti.

Elliot, Richard and Larry Percy. (2007). Strategic Brand Management. Oxford University Press. New York.

Fikri Sirhan, et.al (2016). Pengaruh kualitas pelayanan terhadap kepuasan dan loyalitas mahasiswa (studi pada mahasiswa strata 1 fakultas ilmu social dan politik universitas merdeka malang). Jurnal bisnis \& manajeman. Vol.3 No 1.

Imam, M.D.S. (2011). Konsep Marketing Public Relations (MPR). Jurnal Marketing . IVol 8. No.1.

Karmila, N., \& Suchyadi, Y. (2020). Supervisi Pendidikan Di Sekolah Alam Bogor. Jurnal Pendidikan Dan Pengajaran Guru Sekolah Dasar (JPPGuseda), 03, 31-33. Retrieved from http://journal.unpak.ac.id/index.php/jppguseda

Karsono. (2008). Peran Mediasi Kepuasan Pelanggan, Citra Perusahaan dan Biaya Switching dalam Pengaruh Kualitas Pelayanan Pada Kesetiaan Pelanggan. Fokus Manajerial. Vol 6. No.2.

Kotler, P. and Gary Armstrong. (2008). Prinsip-Prinsip Pemasaran (diterjemahkan oleh Bob Sabran). Erlangga. Jakarta.

Laksana, F. (2008).Manajemen Pemasaran Pendekatan Praktis.Edisi Pertama. Graha Ilmu. Yogyakarta.

Lengkong L, Silviana, dkk. (2017). Strategi Public Relations dalam Pemulihan Citra Perusahaan (Studi Kasus Rumah Makan Kawan Baru Megamas Manado). E-journal “Acta Diurna” Volume VI. No. 1.

Lerpold, Lin, et.al. (2007). Organizational Identity in Practice.Routledge. New York

Mete, Lucia and Dinu, Theodora. (2010). Regulation an best Practice in Public and Nonprofit Marketing.Editura Economica, Bucharest.

Narti, Sri. (2016). Melihat Hubungan Masyarakat dalam Praktik. Jurnal Profesional FIS UNIVED. Vol.3. No.1.

Oliver, Sandra. (2007). Strategi Public Relations. Esensi. Jakarta.

Patras, Yuyun Elizabeth, R.H (2020). Pengembangan instrument kualitas layanan dosen universitas swasta menggunakan pemodelan Rasch. Jurnal Konseling dan Pendidikan. Vol.8 No.1.

Puspokusumo, Aryanti. (2011). Peranan Management Public Relations dalam MempertahankanCitra Perusahaan Jasa Perhotelan : Studi Kualitatif Pada Re-Opening Hotel Mandarin Oriental, Jakarta. BINUS Business Review. Vol. 2 No. 1.

Rahman, Abdul. (2016). Manajemen Humas Sekolah. Media Akademi. Yogyakarta.

Ranguty, F. (2008). Measuring Consumer Satisfaction : Teknik Mengukur dan Strategi Kepuasan Pelanggan, Cetakan Ke empat. Gramedia Pustaka Utama . Jakarta.

Reddi, Narasima. (2009). Effective Public Relation and Media Strategy. PHI Leaerning Private Limited. New Delhi

Rehman M., and Afsar B., (2012). Relationship Among Corporate Image, intangible Perceived Quality, Choosing, Habit and Customer Loyalty, Management and Marketing Journal, Volume X, Issue 1.

Robbi Saepul Rahman. (2016). Pengruh Bauran Hubungan Masyarakat (Public Relation Mix) Terhadap Citra Merek dan Kesadaran Merek Serta Implikasinya Terhadap Keputusan Siswa Memilih Studi. Jurnal Ekonomi, Bisnis \& Entrepreneurship Vol.10, No. 1, April 2016, 44-59 ISSN 2443- 2121. STIE Pasundan, Bandung

Tangkilisan, Hessel Nogi. (2007). Manajemen Publik, Cetakan Kedua. Penerbit: Grasindo. Jakarta.

Zulkarnaen Nasution.(2010). Manajemen Humas di Lembaga Pendidikan; Konsep, Fenomena, dan Aplikasinya. Malang. 